\title{
Latent infection of Biscogniauxia nummularia in Fagus sylvatica: a possible bioindicator of beech health conditions
}

Nicola Luchi ${ }^{(1)}$, Paolo Capretti ${ }^{(2)}$, Matteo Feducci ${ }^{(2)}$, Andrea Vannini ${ }^{(3)}$, Barbara Ceccarelli ${ }^{(3)}$, Anna Maria Vettraino $^{(3)}$

\begin{abstract}
Biscogniauxia nummularia is a xylariaceous fungus known as a common endophyte of European beech, living in plant tissues without development of symptoms, or even inducing strip-cankers and wood decay on trees stressed by drought. We studied the presence of the fungus in apparently healthy beech trees, growing in two different bioclimatic zones characterized by Continental and Mediterranean climates. Asymptomatic twigs were collected in each zone over the season and evaluated for the presence of $B$. nummularia infections using both cultural and GPCR methods. Results from qPCR indicated differences in the detection of $B$. nummularia among the seasons and between the study sites. In both sites the highest frequency of detection was in summer. $B$. nummularia was more frequently detected in the Mediterranean bioclimatic area, where drought is more common. These results suggest that $B$. nummularia may be a possible bioindicator of beech health stands.
\end{abstract}

\section{Keywords: Fagus sylvatica, Latent Pathogen, Real Time PCR, Xylariaceae}

thern Apennines have greater affinity with the Alpine beech forests than with those in central Italy (Pignatti 1998, Piovesan et al. 2005). Because of its longevity, widespread distribution, and climate sensitivity, beech is a potential species for bio-monitoring programs on the status of European temperate forests (Biondi 1993, Piovesan \& Adams 2001, Nielsen \& Jørgensen 2003, Piovesan et al. 2005).

In a scenario of global climatic change, drought is expected to become one of the most limiting factors to beech forest sustainability, especially at lower latitudes (Weber et al. 2013). Monitoring of drought events and their impact on beech therefore are paramount needs in order to evaluate the latitudinal and altitudinal migration of the species and develop adaptation strategies. Immediate consequences of drought events on beech are extensive mortality of fine roots during peak drought
(1) National Research Council - Institute for Sustainable Plant Protection, (CNR-IPSP), Via Madonna del Piano 10, I- 50019 - Sesto Fiorentino, Firenze (Italy); (2) Department of Agrifood Production and Environmental Sciences, University of Florence (DISPAA). Piazzale delle Cascine, 28, I-50144, Firenze (Italy); (3) Department for Innovation in Biological, Agro-food and Forest Systems, University of Tuscia (DIBAF), Via San Camillo De Lellis, I- 01100, Viterbo (Italy)

@ Nicola Luchi (nicola.luchi@ipsp.cnr.it)

Received: Aug 29, 2014 - Accepted: Mar 05, 2015

Citation: Luchi N, Capretti P, Feducci M, Vannini A, Ceccarelli B, Vettraino AM (2015). Latent infection of Biscogniauxia nummularia in Fagus sylvatica: a possible bioindicator of beech health conditions. iForest 9: 49-54. - doi: 10.3832/ifor1436-008 [online 2015-06-18]

Communicated by: Elena Paoletti
(Leuschner et al. 2004), and an increase in host susceptibility to secondary pathogens (Schoeneweiss 1975, Desprez-Loustau et al. 2006). Several pathogens attack beech trees opportunistically after extended drought, such as the root rot fungi Armillaria spp. and occasionally Heterobasidion annosum (Wargo 1983, Capretti 1998, Popoola \& Fox 2003, Capretti et al. 2007, Lakomy \& Cieslak 2008). Other opportunistic pathogens that normally colonize symptomless tissue may have an indirect effect on the survival of stressed trees. Among these pathogens, Biscogniauxia nummularia, a Xylariaceous fungus, has been found in stressed beech trees (Granata \& Whalley 1994, Paoletti et al. 1996, Capretti et al. 2003, Granata \& Sidoti 2004). This fungus spends part of its life cycle as endophyte and may induce disease symptoms on its host under unfavorable environmental conditions. In prolonged summer drought, B. nummularia takes advantage of the altered host physiology, invades host tissue and causes elongated blackish bark lesions on trunk and branches, known as strip-cankers, and wood decay in mature trees (Hendry et al. 1998, Nugent et al. 2005). In the related species B. mediterranea (Vannini et al. 2009), outbreak of disease on oaks is likely to follow an increase in endophytic colonization. Therefore, monitoring of the endophytic stage of these fungi may provide an indication of droughtinduced stress conditions of the host (Desprez-Loustau et al. 2006), i.e., the water deficit that can predispose the plant to disease (Boyer 1995, Schoeneweiss 1975).

The detection of opportunistic pathogens within symptomless tissue is of primary importance to study disease progress and 


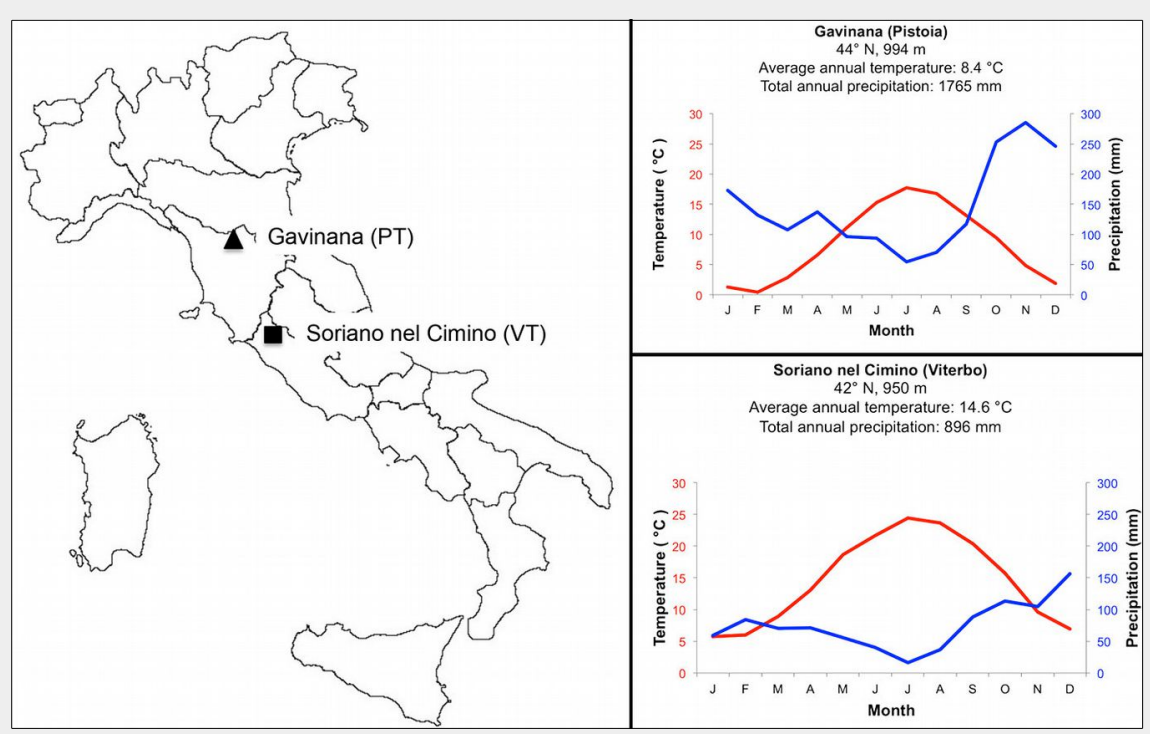

Fig. 1 - (Left panel): location of beech-sampling areas along the Apennines Mountains; (right panel): Walter-Lieth diagram of the two sampling sites in the period 2003-2008.

particularly the transition from latent to active tissue colonization. This process may also account for seasonal disease outbreaks caused by opportunistic pathogens, especially when these diseases are related to host decline.

In the past, the occurrence of endophytic microorganisms in healthy trees and the seasonality of occurrence in woody plants was detected by isolation from tissues on growth media in order to obtain axenic fungal cultures (Hallmann et al. 2006). However, these traditional isolation methods probably underestimate the frequency of a target microorganism (Catal et al. 2001).

Over recent years, rapid and sensitive molecular methods, such as real-time quantitative PCR ( $\mathrm{PPCR}$ ), have been developed to identify and quantify bacteria (PalacioBielsa et al. 2011) and fungi from woody plants, before symptoms occur in the host (Luchi et al. 2005, 2006). The effectiveness of this molecular method allows a target pathogen to be quantified directly in DNA extracted from plant tissue, reducing the time of diagnosis.

The aim of the work reported here was to investigate the potential of $B$. nummularia as bioindicator of beech health conditions in Italy, using a qPCR assay (Luchi et al. 2006) to assess the occurrence of this fungus in asymptomatic twigs.

Tab. 1 - Characteristics of beech sampling forests in the Apennine Mountains (Italy).

\begin{tabular}{lccccc}
\hline $\begin{array}{l}\text { Sampling } \\
\text { site }\end{array}$ & $\begin{array}{c}\text { Longitude } \\
\mathrm{N}\end{array}$ & $\begin{array}{c}\text { Latitude } \\
\mathrm{E}\end{array}$ & $\begin{array}{c}\text { Elevation } \\
(\mathrm{m} \text { a.s.l.) }\end{array}$ & $\begin{array}{c}\text { Phytoclimatic } \\
\text { unit }\end{array}$ & $\begin{array}{c}\text { Xerothermic } \\
\text { index }\left(X_{\mathbf{i}}\right)\end{array}$ \\
\hline $\begin{array}{l}\text { Soriano nel } \\
\text { Cimino (VT) }\end{array}$ & $42^{\circ} 24^{\prime} 36.9^{\prime \prime}$ & $12^{\circ} 12^{\prime} 08.9^{\prime \prime}$ & 950 & $\begin{array}{c}\text { Aquifolio-Fagion } \\
\text { Mediterranean } \\
\text { climate }\end{array}$ & 38.5 \\
$\begin{array}{l}\text { Gavinana } \\
\text { (PT) }\end{array}$ & $44^{\circ} 04^{\prime} 07.9^{\prime \prime}$ & $10^{\circ} 48^{\prime} 41.7^{\prime \prime}$ & 994 & $\begin{array}{c}\text { Luzulo-Fagion } \\
\text { Sub-continental } \\
\text { climate }\end{array}$ & 0 \\
\hline
\end{tabular}

vinana) and $14.8^{\circ} \mathrm{C}$ (Soriano del Cimino). For each sampling area a xerothermic index $\left(X_{\mathrm{i}}\right)$ was calculated using the following formula (eqn. 1):

$$
X_{i}=\left\{\begin{array}{cc}
\sum(2 T M-P) & \text { if }(2 T M>P) \\
0 & \text { if }(2 T M \leqslant P)
\end{array}\right.
$$

where $T M$ is the monthly mean of the maximum and minimum temperatures in ${ }^{\circ} \mathrm{C}$ and $P$ is the monthly precipitation in $\mathrm{mm}$ (Grossmann et al. 2002). $X_{\mathrm{i}}$ was calculated on a historical data series from the last 10 years (1997-2007).

Previous studies showed the presence of Phytophthora cactorum and B. nummularia in the Soriano del Cimino forest (Vettraino et al. 2008, Ceccarelli 2011), while in Gavinana the stromata of $B$. nummularia were mainly associated with declining beech trees, especially on the edge of the forest (Ginanni 2007).

\section{Latent infections of $\mathrm{B}$. nummularia}

For each area two slopes (N-S) were chosen in the same growing conditions and 10 asymptomatic beech trees of the same age (five on a northern and five on a southern facing slope) were arbitrarily selected inside the forest. Site topographies were gently sloping (5\%). No symptomatic beech trees were present close to those sampled. Each tree was numbered and its position registered with GPS for the subsequent sampling. From each tree, three arbitrarily selected apical portions of current-year shoots were collected from the lower part of the crown, with a total of 30 twigs per stand. Collections were made in autumn (25 October 2007), winter (13 February 2008), spring ( 3 June 2008) and summer (1 September 2008). A total of 240 twigs were collected.

Twig segments $(30 \mathrm{~mm}$ length, $5-6 \mathrm{~mm}$ diameter) were surface sterilized in the lab with $75 \%$ ethanol ( $1 \mathrm{~min}$ ), 3\% $\mathrm{NaClO}$ (3 min) and $75 \%$ ethanol (30 s) and rinsed three times with sterile water (Lodge et al. 1996). Each twig was split longitudinally into two parts containing both wood and bark tissue: one part was utilized for DNA extraction and the second for fungal culturing in agar media. The portion of twig used for fungal isolation was cut into 15 small fragments (2-3 mm each), placed on $1.5 \%$ PDA (potato dextrose agar - Difco, Milan, Italy) and incubated in darkness at $20^{\circ} \mathrm{C}$ for 10 days (Luchi et al. 2006).

The portions of twigs used for DNA extraction (100 mg fresh weight) were transferred to 2-ml microfuge tubes and ground with a Mixer Mill $300^{\circledR}$ (Qiagen, Valencia, CA, USA) for 2 min $(20 \mathrm{~Hz})$. DNA was extracted from all samples using the DNeasy ${ }^{\circledR}$ Plant Minikit (Qiagen), as described previously (Luchi et al. 2006). B. nummularia DNA was detected and quantified by realtime quantitative PCR (qPCR) using specific primers and the TaqMan ${ }^{\text {TM }}$ probe (Luchi et al. 2006). Quantitation of B. nummularia DNA was expressed as pg per mg fresh 
twig weight (pg fungal DNA/mg fw).

\section{Data analysis}

Frequency of occurrence (OF) of B. nummularia was calculated with the formula (eqn. 2):

$$
O F(\%)=\frac{N_{i}}{N_{t}} \cdot 100
$$

where $N_{\mathrm{i}}$ is the number of twig segments in which B. nummularia was detected and $N_{\mathrm{t}}$ is the total number of segments tested.

Statistical analysis of data on the detection of B. nummularia among trees in each area, between sites, detection methods and seasons was calculated using the $\chi^{2}$ test. The D'Agostino-Pearson $K^{2}$ test (D'Agostino \& Pearson 1973) was applied to test for departure from normality of data $(\alpha=0.05)$. Data were also tested for homogeneity of variances using the Levene's test, and equality of variances using plots of residuals and the Shapiro-Wilks test. Comparisons of differences in the amount of $B$. nummularia were performed after log transformation. The results were analysed using one-way analysis of variance (ANOVA $-\alpha=0.05)$. Differences among means were tested by the post-hoc Tukey's test ( $\alpha=$ 0.05). An unpaired, two-tails test (t-test) was used to compare the sampling periods between sites. The temporal trend in $B$. nummularia abundance was analyzed by regression analysis using $B$. nummularia abundance (total pg fungal DNA) as dependent variable and the precipitation of the month before sampling $(\mathrm{mm})$ as predictor. DNA data were log transformed to take into consideration the multiplicative effect of the independent variable (precipitation). All analyses were performed using the Graphpad Instat ${ }^{\oplus}$ software (San Diego, CA, USA).

\section{Results}

\section{Detection of $B$. nummularia in}

symptomless beech trees

A total of 240 F. sylvatica twigs (120 for each forest) were processed to determine the presence of $B$. nummularia. The fungus was detected from samples using both cultural and molecular methods.

Frequency of occurrence of the fungus at each site was not significantly influenced by the tree aspect $\left(X_{[1]}^{2}=2.09 ; P>0.05\right)$, thus data from both sites were pooled. No significant differences $\left(X_{[1]}^{2}=0.02 ; P>0.05\right)$ were found in the annual frequency of occurrence of $B$. nummularia between the Soriano nel Cimino (OF $=25 \%$ ) and Gavinana $(\mathrm{OF}=23.3 \%)$ sites. No differences in isolation were observed between single trees. B. nummularia was significantly more frequently found using qPCR (72.5\%) than the cultural method $\left(24.1 \%-\chi_{[1]}^{2}=112.2 ; \mathrm{P}<\right.$ 0.001). Overall frequency of detection using $\mathrm{qPCR}$ was greater for samples from Soriano nel Cimino (90.8\%) than for those collected in Gavinana (54.1\% - $\chi_{[1]}^{2}=40$; $\mathrm{P}<$ 0.001). Due to the higher sensitivity of the
Tab. 2 - Results of Biscogniauxia nummularia detection by qPCR from beech trees growing in two different forests in central Italy. Sampling periods: Autumn 2007, Win ter 2008, Spring 2008 and Summer 2008.

\begin{tabular}{|c|c|c|c|c|c|c|}
\hline \multirow{2}{*}{$\begin{array}{l}\text { Sampling } \\
\text { period }\end{array}$} & \multirow{2}{*}{ Pres/Abs } & \multicolumn{2}{|c|}{$\begin{array}{l}\text { qPCR detection of } B \text {. nummularia n. (\%) } \\
\text { of twigs inspected (out of } 30 \text { twigs) }\end{array}$} & \multirow{2}{*}{ Total } & \multirow{2}{*}{$x^{2}$} & \multirow{2}{*}{$\mathbf{P}$} \\
\hline & & $\begin{array}{l}\text { Gavinana } \\
\text { (PT) }\end{array}$ & $\begin{array}{l}\text { Soriano nel } \\
\text { Cimino (VT) }\end{array}$ & & & \\
\hline \multirow[t]{3}{*}{ Autumn } & Presence & $8(26.7)$ & $29(96.7)$ & 37 & 31.09 & $<0.001$ \\
\hline & Absence & $22(73.3)$ & $1(3.3)$ & 23 & & \\
\hline & Total & $30(100)$ & 30 (100) & 60 & & \\
\hline \multirow{3}{*}{ Winter } & Presence & $10(33.3)$ & $30(100)$ & 40 & 30.00 & $<0.001$ \\
\hline & Absence & $20(66.6)$ & 0 & 20 & & \\
\hline & Total & $30(100)$ & $30(100)$ & 60 & & \\
\hline \multirow[t]{3}{*}{ Spring } & Presence & 30 (100) & $26(86.7)$ & 56 & 4.28 & 0.04 \\
\hline & Absence & 0 & $4(13.3)$ & 4 & & \\
\hline & Total & 30 (100) & 30 (100) & 60 & & \\
\hline \multirow[t]{3}{*}{ Summer } & Presence & 17 (56.7) & $24(80.0)$ & 41 & 1.4 & $>0.05$ \\
\hline & Absence & $13(43.3)$ & $6(20.0)$ & 19 & & \\
\hline & Total & $30(100)$ & 30 (100) & 60 & & \\
\hline
\end{tabular}

molecular detection method, only data based on qPCR were used in further analyses.

\section{Seasonality of B. nummularia occurrence}

The percentage of qPCR-positive twig samples was significantly higher in the Soriano nel Cimino than in Gavinana site both in autumn $\left(\chi_{[1]}^{2}=22.5 ; \mathrm{P}<0.001\right)$ and winter $\left(X_{[1]}^{2}=28.7 ; P<0.001\right)$. In contrast, spring detection of $B$. nummularia was higher in twigs collected at Gavinana (100\%) than at Soriano nel Cimino $\left(86.7 \%-\chi_{[1]}^{2}=4.28\right.$; $\mathrm{P}=0.04$ - Tab. 2). As for summer, no significant differences were observed between the two sampling sites $\left(\chi_{[1]}^{2}=1.4 ; P>0.05\right.$ Tab. 2).

B. nummularia DNA in symptomless beech tissues was quantified by GPCR for each sample in both forests. Quantities ranged from $1.14 \mathrm{E}-02$ to $2.26 \mathrm{E}+06 \mathrm{pg} / \mathrm{mg}$ of fresh weight beech tissue. Results from ANOVA showed significant differences in fungal DNA among sampling periods both in Soriano nel Cimino $\left(\mathrm{F}_{[1,119]}=80.07 ; \mathrm{P}<\right.$ 0.001) and Gavinana $\left(\mathrm{F}_{[1,119]}=319.9 ; \mathrm{P}<\right.$ $0.001)$. An increasing trend in the amount of fungal DNA was detected along the vegetative season, with a minimum in autumn (Soriano nel Cimino) or winter (Gavinana), and the maximum in summer at both sites (Fig. 2). The amount of B. nummularia DNA in healthy beech twigs was significantly higher in summer in Soriano nel Cimino (unpaired test, $\mathrm{P}=0.035$ ) than in Gavinana (Fig. 2). No significant differences were detected for the other sampling periods (unpaired test, $\mathrm{P}>0.05$ ).

Regression analysis revealed that pathogen occurrence (in terms of DNA amount detected) was inversely proportional to

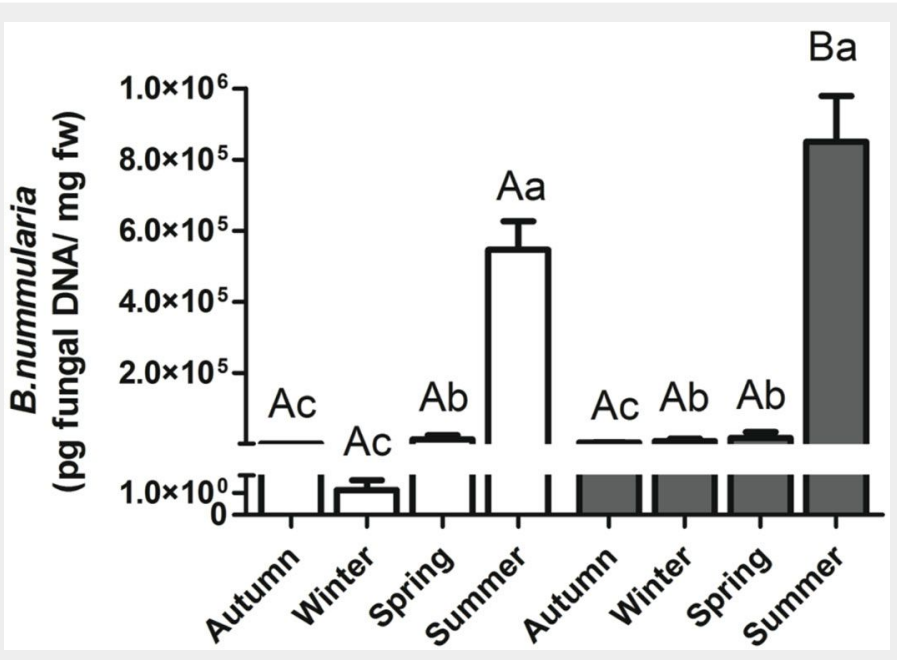

Fig. 2 - Quantification of Biscogniauxia nummularia DNA using qPCR in the northern (Gavinana, PT - white bars) and central Apennines (Soriano nel Cimino, VT - grey bars), in Autumn 2007, Winter 2008, Spring 2008 and Summer 2008. Different lowercase letters indicate significant differences among seasons (ANOVA, $P<0.05$ ). Different capital letters indicate significant differences between two sites in the same season (Unpaired test, $\mathrm{P}<0.05$ ). Bars and whiskers represent the standard error and the mean value, respectively. 


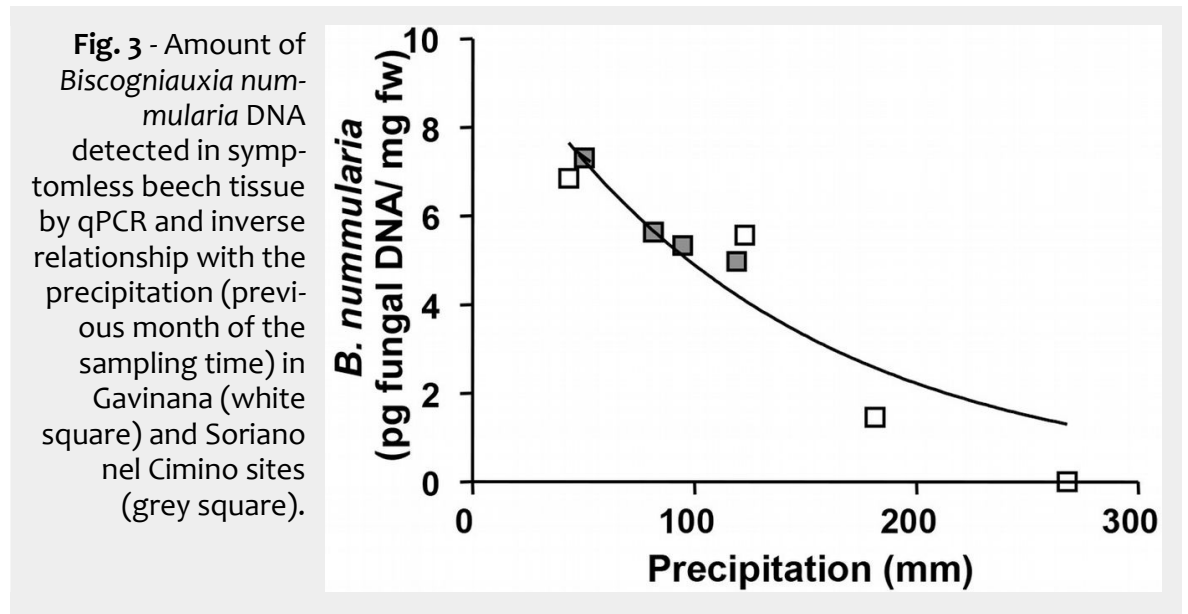

the total precipitation of the month preceding the sampling $\left(P<0.05, R^{2}=0.86\right.$ - Fig. 3).

\section{Discussion}

The results of this investigation confirmed that a specific qPCR assay could be used to detect $B$. nummularia DNA in the apical shoots of Fagus sylvatica, as already reported in a previous study (Luchi et al. 2006). The qPCR technique has been successfully applied to quantify the fungal pathogen in a range between $1.14 \mathrm{E}-02$ to $2.26 \mathrm{E}+06 \mathrm{pg} / \mathrm{mg}$ of fresh weight. The sensitivity of this technique has significantly improved in the last few years. Indeed, qPCR is currently a reliable method to detect even small amounts of latent pathogens in the trees, before visible symptoms occur in the host (Luchi et al. 2005, Maresi et al. 2007).

Differential patterns of B. nummularia occurrence in symptomless beech trees in the two Apennines forests were likely due to their different climatic regimes, Mediterranean in Soriano nel Cimino (VT), and continental in Gavinana (PT). However, more pronounced differences in $B$. nummularia DNA amounts were observed in tissues at the end of the growing season in the site characterized by a warmer climate $\left(X_{\mathrm{i}}=\right.$ 38.5), and with a longer arid period (Fig. 1). In this context, it can be hypothesized that water stress in beech stands may lead to an increase of the amounts of fungal inoculum within apparently healthy tissue, with possible changes in host susceptibility.

Interactions between water stress and the activity of forest pathogens have been recognized since long time (Paoletti et al. 2001, Moricca \& Ragazzi 2008, Jactel et al. 2012). Both air moisture and soil drought have important roles in the epidemiology of tree diseases. Drought-induced tree diseases are often caused by secondary pathogens with endophytic abilities developing in secondary tissues (bark/wood) of stressed hosts (La Porta et al. 2008). Such fungi may establish interactions with the tree ranging from mutualism to antagonism depending on host physiology and environmental conditions. Nevertheless, water stress can trigger the disease development by endophytic fungi in asymptomatic hosts. In this sense, the presence of genic endophytes can reflect physical changes in the environment (Desprez-Loustau et al. 2006).

In this study fluctuations in the amounts of B. nummularia were also observed in symptomless beech twigs, with significant differences occurring among sampling periods in both sites. The amount of fungal DNA was significantly higher during the vegetative season (summer) in both sampled forests. From an ecological point of view, B. nummularia behaves in a similar way to $B$. mediterranea, which proliferates in asymptomatic tissues of Q. cerris during dry growing seasons (Vannini et al. 2009).

The increase of quantities of $B$. nummularia within symptomless tissues may have a negative impact on beech health, possibly inducing the outbreak of disease, when climatic or host conditions change. Previous studies have also suggested that plant pathogenic fungi with endophytic behavior are sensitive to variations in host physiology driven by stress conditions (Leuschner et al. 2004, Desprez-Loustau et al. 2006). In conifers, outbreaks of Diplodia sapinea have been attributed to several stress factors and experimental work has underlined the interaction with water stress in the Pinus - D. sapinea pathosystem (Stanosz et al. 2001, Paoletti et al. 2001). In Fagaceae species of the Mediterranean area, $B$. mediterranea - the causal agent of charcoal disease of oak - can rapidly colonize the xylem and bark tissues of Q. cerris and Quercus ilex ssp. ballota subjected to water stress, inducing necrosis and canker formation and accelerating tree decline and death (Desprez-Loustau et al. 2006, Jurc \& Ogris 2006, Capretti \& Battisti 2007). Water stress favors the proliferation of the fungus in the endophytic phase; the pathogenic ability of B. mediterranea induces cankers and wood decay (Vannini \& Scarascia Mugnozza 1991, Collado et al. 1999, Vannini et al. 2009). Similarly, Bassett \& Fenn (1984) showed that asymptomatic seedlings of Quercus alba L. and Q. velutina Lam. and fluctuations in populations of patho- naturally infected with B. atropunctata were rapidly colonized by the pathogen under water stress conditions.

The richness of fungal endophyte populations is strictly related to environmental parameters, such as temperature and rain (Hashizume et al. 2010, Zimmerman \& Vitousek 2012). Recently, it was shown that the composition of leaf-associated fungi on F. sylvatica is correlated primarily with the annual mean temperature (Cordier et al. 2012, Coince et al. 2014). In the present work, the detection B. nummularia DNA in symptomless tissue of beech showed a significant decreasing trend as the mean precipitation of the month preceding the sampling increases $\left(R^{2}=0.86\right)$, i.e., the amount of latent infection increased with decreasing precipitation. A relationship between environmental parameters and fungal behavior has been observed in several studies. Gange et al. (2011) showed that changing temperature and rainfall regimes cause different germination and growth rates of Auricularia auricula-judae. Straatsma et al. (2001) observed a correlation between the time of fruitbody appearance and temperature in a Swiss forest plot. In the Diplodia-Austrian pine pathosystem variations in the quantities of $D$. sapinea DNA in healthy pine shoots was positively correlated with the yearly amount of solar radiation received by trees (Maresi et al. 2007).

Variation in latent pathogens in apparently healthy plant tissues is important to consider when monitoring the health status of plants. Usually symptoms caused by biotic or abiotic factors represent successful bioindicators in assessing the health of forest trees (Schütt 1989). However, several studies have demonstrated the effectiveness of flora such as lichens as bioindicators of forest health (Loppi \& Pirintsos 2003, Jeran et al. 2007, Mayer et al. 2009). Fungi colonizing plant tissues also could be considered as potential bioindicators of environmental changes. For example, Helander (1995) found a negative effect of air pollution on fungal endophytes in pine needles along a gradient from two factory complexes. Recently, Romeralo et al. (2012) showed that the frequency of fungi inside pine needles was negatively correlated with air quality. Furthermore, fungal endophytes were also used as bioindicators of tree vitality. Several authors reported a negative correlation between needle fungal endophytes and P. abies vitality (Barklund \& Rowe 1983, Sieber 2007, Rajala et al. 2013). Some fungal species may change their behavior towards a plant host after the alteration of environmental conditions (Sieber 2007, Botella \& Diez 2011).

The ability of latent pathogens to quickly adapt to new environmental conditions suggests that these organisms could be used as bioindicators of forest health (Vannini et al. 2009, Romeralo et al. 2012), in that: (i) their presence can be easily detected; (ii) they are sufficiently sensitive to provide an early warning of change; (iii) 
they are widely applicable, and independent of sample size. Such characteristics match the criteria for their selection as good markers (Juutinen et al. 2006). In this study, B. nummularia was easily detected using a molecular method based on qPCR. In addition, the fungus occurred more frequent in the Mediterranean bioclimatic area, in which beech trees are more susceptible to drought stress, predisposing the host to fungal disease.

\section{Conclusions}

The identification of target species or functional groups for assessing the effects of climate on forests is particularly important in a scenario of global climatic change that affects the ecosystem functions and the survival of species (Staudinger et al. 2012). Italy and the Mediterranean basin in general are considered hot-spots for climatic change. Models for these areas predict extreme climatic events with prolonged drought periods and anomalous precipitation events that might seriously affect sustainability of several ecosystems (Coakley et al. 1999). Forests are particularly sensitive to climate change, because the long lifespan of trees does not allow for a rapid adaptation response (IPCC 2007).

Tools for assessing the general health status of individual trees or forest community, as well as for forecasting the outbreak of complex decline syndromes, may increase in importance in the next future. During recent years, climate change has altered host distributions, with shifts towards higher altitudes (IPCC 2007). This phenomenon has been observed in several tree species, including European beech that shifted upwards at the highest altitudes, displacing heath lands and grasslands and a few conifer species (Peñuelas et al. 2007). Such shifts could potentially favor the spread of pathogens into new bioclimatic zones causing additional damage. Considering that beech is a common forest species along the Italian peninsula and is particularly sensitive to climatic conditions, the interactions of beech with $B$. nummularia (or potentially other Xylariaceous endophytes) might be used as a tool in monitoring the health status of mountain forests. The seasonal variation in fungal quantities within healthy beech tissues suggest that B. nummularia should be considered a possible bioindicator of beech health condition.

\section{Acknowledgments}

This paper is dedicated to the memory of Prof. Francesco Moriondo (1926-2014).

This work was supported by DIGESFAM ("DIfesa e GEStione FAggete Mediterranee" - Ministero delle Politiche Agricole e Forestali, Italy) and BACCARA ("Biodiversity And Climate Change, A Risk Analysis" European Community's Seventh Framework Program FP7/2007-2013) under the grant agreement $\left.n^{\circ} 226299\right)$ projects. The authors are grateful to Prof. Stephen Woodward (University of Aberdeen, UK) for a critical review of the manuscript. We also appreciate the helpful comments and suggestions from the anonymous reviewers.

\section{References}

Barklund P, Rowe J (1983). Endophytic fungi in Norway spruce - possible use in bioindicator of vitality. Aquilo Serier Botanicae 19: 228-232.

Bassett EN, Fenn P (1984). Latent colonization and pathogenicity of Hypoxylon atropunctatum on oaks. Plant Disease 68: 317-319. - doi: 10.1094/PD-68-317

Biondi F (1993). Climatic signals in tree-rings of Fagus sylvatica $L$. from the central Apennines, Italy. Acta Oecologica 14: 57-71. [online] URL: http://wolfweb.unr.edu/homepage/fbiondi/Bio n di1993.pdf

Botella L, Diez JJ (2011). Phylogenic diversity of fungal endophytes in Spanish stands of Pinus halepensis. Fungal Diversity 47: 9-18. - doi: 10.1007/s13225-010-0061-1

Boyer JS (1995). Biochemical and biophysical aspects of water deficits and the predisposition to disease. Annual Review of Phytopathology 33: 251-274. - doi: 10.1146/annurev.py.33.090195. 001343

Capretti P (1998). Impact, control and management of Heterobasidion annosum. Italy. In: "Heterobasidion annosum: Biology, Ecology, Impact and Control" (Woodward S, Stenlid J, Karjalainen $R$, Hüttermann $A$ eds). CAB International, Wallingford, UK, pp. 377-385.

Capretti P, Menguzzato G, Maresi G, Luchi N, Moriondo F (2003). Fenomeni di deperimento e di moria in popolamenti artificiali misti di latifoglie e conifere [Decay and blight phenomena in mixed artificial populations of broadleaves and conifers]. Annali Accademia Italiana di Scienze Forestali 52: 3-30. [in Italian]

Capretti P, Battisti A (2007). Water stress and insect defoliation promote the colonization of Quercus cerris by the fungus Biscogniauxia mediterranea. Forest Pathology 37:129-135. doi: 10.1111/j.1439-0329.2007.00489.x

Capretti P, Luchi N, Mazza G (2007). Root rot disease by Heterobasidion annosum on Fagus sylvatica stands in southern Italy. Journal of Plant Pathology 89: 34-34.

Catal M, Adam GC, Chastagner GA (2001). Detection, identification and quantification of latent needlecast pathogens and endophytee in symptomless conifer foliage by PCR and DotBlot assays. In: Proceedings of the "IUFRO Working Party 7.02.02 - Shoot and Foliage Diseases". Hyytiala (Finland) 17-22 Jun 2001. Finnish Forest Research Institute Research Papers, Joensuu, Finland, vol. 829, pp. 164-168. Ceccarelli B (2011). Structure and diversity of "pathogenic" and "non-pathogenic" fungal endophyte community of Fagus sylvatica in the Mediterranean Basin. Ph.D. Thesis, Università degli Studi della Tuscia, Viterbo, Italy, pp. 101.

Coakley SM, Scherm H, Chakraborty S (1999). Climate change and disease management. Annual Review of Phytopathology 37: 399-426. - doi: 10.1146/annurev.phyto.37.1.399

Coince A, Cordier T, Lengellé J, Defossez E, Vacher C, Robin C, Buée M, Marçais B (2014). Leaf and root-associated fungal assemblages do not follow similar elevational diversity patterns. PLoS One 9 (6): e100668. - doi: 10.1371/journal. pone. 0100668

Collado J, Platas G, Gonzales I, Pelaez F (1999). Geographical and seasonal influences on the distribution of fungal endophytes in Quercus ilex. New Phytologist 144: 525-532. - doi: 10.1046 /j.1469-8137.1999.00533.x

Cordier T, Robin C, Capdevielle X, Fabreguettes O, Desprez-Loustau ML, Vacher C (2012). The composition of phyllosphere fungal assemblages of European beech (Fagus sylvatica) varies significantly along an elevation gradient. New Phytologist 196: 510-509. - doi: 10.1111/j.146 9-8137.2012.04284.x

D’Agostino R, Pearson ES (1973). Tests for departure from normality. Empirical results for the distributions of b2 and Vb1. Biometrika 60: 613622.

Desprez-Loustau ML, Marcais B, Nageleisen LM, Piou DA, Vannini A (2006). Interactive effects of drought and pathogens in forest trees. Annals of Forest Science 63: 597-612. - doi: 10.1051/ forest:2006040

Di Pietro R (2009). Observation on the beech woodlands of the Apennines (peninsular Italy): an intricate biogeographical and syntaxonomical issue. Lazaroa 30: 89-97.

Dittmar C, Zech W, Elling W (2003). Growth variations of common beech (Fagus sylvatica L.) under different climatic and environmental conditions in Europe - a dendroecological study. Forest Ecology and Management 173: 63-78. doi: 10.1016/S0378-1127(01)00816-7

Gange AC, Gange EG, Mohammad AB, Boddy L (2011). Host shifts in fungi caused by climate change? Fungal Ecology 4: 184-190. - doi: 10.1016/j.funeco.2010.09.004

Ginanni F (2007). Ruolo dei parametri ambientali e di Biscogniauxia nummularia nella formazione di necromassa in un ceduo di faggio dell'Appenino Pistoiese. [Role of environmental parameters and Biscogniauxia nummularia in the formation of deadwood in a beech coppice in the Apennines (Pistoia)]. M.Sc. thesis in Environmental and Forest Science, University of Florence, Italy, pp. 37.

Granata G, Sidoti A (2004). Biscogniauxia nummularia: pathogenic agent of a beech decline. Forest Pathology 34: 363-367. - doi: 10.1111/j.14 39-0329.2004.00377.x

Granata G, Whalley JSA (1994). Decline of beech associated to Biscogniauxia nummularia in Italy. Petria 4: 111-116.

Grossmann A, Romane F, Grandjanny M (2002). The climate environment of the "CASCADE" sites. EU Project EVK2-CT-1999-00006 II Report, CNRS-CEFE, Montpellier, France, pp. 70.

Hallmann J, Berg G, Schulz B (2006). Isolation procedures for endophytic microorganisms. In: "Microbial Root Endophytes" (Schulz B, Boyle CJC, Sieber TN eds). Soil Biology Series (vol. 9), Springer-Verlag, Berlin, Heidelberg, Germany, pp. 299-319. - doi: 10.1007/3-540-33526-9_17

Hashizume Y, Fukuda K, Sahashi N (2010). Effects of summer temperature on fungal endophyte assemblages in Japanese beech (Fagus crenata) leaves in pure beech stands. Botany 88: 266-274. - doi: 10.1139/Bo9-114

Helander ML (1995). Responses of pine needle 
endophytes to air pollution. New Phytologist 131: 223-229. - doi: 10.1111/j.1469-8137.1995.tbo5 723.x

Hendry SJ, Lonsdale D, Boddy L (1998). Stripcankering of beech (Fagus sylvatica): pathology and distribution of symptomatic trees. New Phytologist 140: 549-565. - doi: 10.1046/j.14698137.1998.00282.x

IPCC (2007). Climate change 2007: impacts, adaptation and vulnerability. Contribution of working group II to the fourth assessment report of the intergovernmental panel on climate change (Parry ML, Canziani OF, Palutikof JP, Van Der Linden PJ, Hanson CE eds). Cambridge University Press, Cambridge, UK, pp. 976.

Jactel H, Petit J, Desprez-Loustau ML, Delzon S, Piou D, Battisti A, Koricheva J (2012). Drought effects on damage by forest insects and pathogens: a meta-analysis. Global Change Biology 18: 267-276. - doi: 10.1111/j.1365-2486.2011. 02512.x

Jeran Z, Mrak T, Jacimovic R, Batic F, Kastelec D, Mavsar R, Simoncic P (2007). Epiphytic lichens as biomonitors of atmospheric pollution in Slovenian forests. Environmental Pollution. 146: 324-331.

Juutinen A, Mönkkönen M, Sippola AL (2006). Cost-efficiency of decaying wood as a surrogate for overall species richness in boreal forests. Conservation Biology 20: 74-84. - doi: 10.1111/j.1523-1739.2005.00306.x

Jurc D, Ogris N (2006). First reported outbreak of charcoal disease caused by Biscogniauxia mediterranea on Turkey oak in Slovenia. Plant Pathology 55 (2): 299-299. - doi: 10.1111/j.13653059.2005.01297.x

La Porta N, Capretti P, Thomsen IM, Kasanen R, Hietala AM, Von Weissenberg K (2008). Forest pathogens with higher damage potential due to climate change in Europe. Canadian Journal of Plant Pathology 30: 177-195. - doi: 10.1080/ 07060661.2008.10540534

Leuschner C, Hertel D, Schmid I, Koch O, Muhs A, Holscher D (2004). Stand fine root biomass and fine root morphology in old-growth beech forests as a function of precipitation and soil fertility. Plant and Soil 258: 43-56. - doi: 10.1023/ B:PLSO.0000016508.20173.80

Lakomy P, Cieslak R (2008). Early infection of Fagus sylvatica by Heterobasidion annosum sensu stricto. Forest Pathology 38: 314-319. doi: 10.1111/j.1439-0329.2008.00546.x

Lodge DJ, Fisher PJ, Sutton BC (1996). Endophytic fungi of Manilkara bidentata leaves in Puerto Rico. Mycologia 88: 733-738. - doi: 10.2307/3760967

Loppi S, Pirintsos SA (2003). Epiphytic lichens as sentinels for heavy metal pollution at forest ecosystems (central Italy). Environmental Pollution 121: 327-332. - doi: 10.1016/So269-7491(02) 00269-5

Luchi N, Capretti P, Pinzani P, Orlando C, Pazzagli M (2005). Real-time PCR detection of Biscogniauxia mediterranea in symptomless oak tissue. Letters in Applied Microbiology 41:61-68. doi: 10.1111/j.1472-765X.2005.01701.X

Luchi N, Capretti P, Vettraino AM, Vannini A, Pinzani P, Pazzagli M (2006). Early detection of Biscogniauxia nummularia in symptomless European beech (Fagus sylvatica L.) by TaqMan ${ }^{\mathrm{TM}}$ real-time PCR. Letters in Applied Microbiology 43: 33-38. - doi: 10.1111/j.1472-765X.2006.01920.x Mayer AL, Vihermaa L, Nieminen N, Luomi A, Posch M (2009). Epiphytic macrolichen community correlates with modelled air pollutants and forest conditions. Ecological Indicators 9: 9921000. - doi: 10.1016/j.ecolind.2008.11.010

Maresi G, Luchi N, Pinzani P, Pazzagli M, Capretti $P$ (2007). Detection of Diplodia pinea in asymptomatic pine shoots and its relation to the Normalized Insolation index. Forest Pathology 37: 272-280. - doi: 10.1111/j.1439-0329.2007.00506.x Moricca S, Ragazzi A (2008). Fungal endophytes in Mediterranean oak forests: a lesson from Discula quercina. Phytopathology 98: 380-386. doi: 10.1094/PHYTO-98-4-0380

Nielsen CN, Jørgensen FV (2003). Phenology and diameter increment in seedlings of European beech (Fagus sylvatica L.) as affected by different soil water contents: variation between and within provenances. Forest Ecology and Management 174: 233-249. - doi: 10.1016/So3781127(02)00042-7

Nugent LK, Sihanonth P, Thienhirun S, Whalley AJS (2005). Biscogniauxia: a genus of latent invaders. Mycologist 19: 40-43. - doi: 10.1017/So26 9915X05001060

Palacio-Bielsa A, Cubero J, Cambra MA, Collados R, Berruete IM, López MM (2011). Development of an efficient real-time quantitative PCR protocol for detection of Xanthomonas arboricola pv. pruni in Prunus species. Applied and Environmental Microbiology 77: 89-97. - doi: 10.1128/ AEM.01593-10

Paoletti E, Danti R, Strati S (2001). Pre- and postinoculation water stress affects Sphaeropsis sapinea canker length in Pinus halepensis seedlings. Forest Pathology 31: 209-218. - doi: 10.104 6/j.1439-0329.2001.00237.x

Paoletti E, Goggioli V, Maresi G (1996). Reperti di B. nummularia su faggio in Italia. [Biscogniauxia nummularia on beech in Italy]. Micologia Italiana 1: 27-35. [in Italian]

Peñuelas J, Ogaya R, Boada M, Jump AS (2007). Migration, invasion and decline: changes in recruitment and forest structure in a warminglinked shift of European beech forest in Catalonia (NE Spain). Ecography 30, 829-837. - doi: 10.1111/j.2007.0906-7590.05247.x

Pignatti S (1998). I boschi d'Italia [Italian woods]. UTET, Torino, Italy, pp. 667. [in Italian] Piovesan G, Adams JM (2001). Masting behavior in beech: linking reproduction and climatic variation. Canadian Journal of Botany 79: 10391047. - doi: 10.1139/bo1-089

Piovesan G, Biondi F, Bernabei M, Di Filippo A, Schirone B (2005). Spatial and altitudinal bioclimatic zones of the Italian peninsula identified from a beech (Fagus sylvatica L.) tree-ring network. Acta Oecologica 27: 197-210. - doi: 10.101 6/j.actao.2005.01.001

Popoola TOS, Fox RTV (2003). Effect of water stress on infection by species of honey fungus (Armillaria mellea and A. gallica). Arboricultural Journal 27: 139-154. - doi: 10.1080/03071375.20 03.9747369

Rajala T, Velmala SM, Tuomivirta T, Haapanen M, Müller M, Pennanen T (2013). Endophyte communities vary in the needles of Norway spruce clones. Fungal Biology 117: 182-90. - doi: 10.1016/ j.funbio.2013.01.006
Romeralo C, Diez JJ, Santiago NF (2012). Presence of fungi in Scots pine needles found to correlate with air quality as measured by bioindicators in northern Spain. Forest Pathology 42: 443-453. - doi: 10.1111/efp.12002

Schoeneweiss DF (1975). Predisposition, stress, and plant disease. Annual Review of Phytopathology 13: 193-211. - doi: 10.1146/annurev.py.13. 090175.001205

Schütt P (1989). Symptoms as bioindicators of decline in European forests. In: "Committee on Biologic Markers of Air-Pollution Damage in Trees". National Research Council, National Academy Press, Washington DC, USA, pp. 119124.

Sieber TN (2007). Endophytic fungi in forest trees: are they mutualists? Fungal Biology Review 21: 75-89. - doi: 10.1016/j.fbr.2007.05.004

Stanosz GR, Blodgett JT, Smith DR, Kruger EL (2001). Water stress and Sphaeropsis sapinea as a latent pathogen of red pine seedlings. New Phytologist 149: 531-538. - doi: 10.1046/j.1469-81 37.2001.00052. $\mathrm{x}$

Staudinger MD, Grimm NB, Staudt A, Carter SL, Chapin FSIII, Kareiva P, Ruckelshaus M, Stein BA (2012). Impacts of climate change on biodiversity, ecosystems, and ecosystem services: technical input to the 2013 National climate assessment. Cooperative Report to the 2013 National Climate Assessment, Palo Alto, CA, USA, pp. 296. [online] URL: http://pubs.er.usgs. gov/publication/70039460

Straatsma G, Ayer F, Egli S (2001). Species richness, abundance, and phenology of fungal fruit bodies over 21 years in a Swiss forest plot. Mycological Research 105: 515-523. - doi: 10.1017/ So953756201004154

Vannini A, Lucero G, Anselmi N, Vettraino AM (2009). Response of endophytic Biscogniauxia mediterranea to variation in leaf water potential of Quercus cerris. Forest Pathology 39: 8-14. - doi: 10.1111/j.1439-0329.2008.00554.x

Vannini A, Scarascia Mugnozza G (1991). Water stress: a predisposing factor in the pathogenesis of Hypoxylon mediterraneum on Quercus cerris. European Journal of Forest Pathology 21: 193-201. - doi: 10.1111/j.1439-0329.1991.tboo970.x Vettraino AM, Jung T, Vannini A (2008). First report of Phytophthora cactorum associated with beech decline in Italy. Plant Disease 92: 1708. - doi: 10.1094/PDIS-92-12-1708A

Wargo PM (1983). Armillaria mellea and mortality of beech affected by beech bark disease. In: Proceedings of the "IUFRO Beech Bark Disease Working Party Conference”. Hamden (CT, USA) Sep 26-Oct 8 1982. Gen. Tech. Rep. WO-37, Northeastern Forest Experiment Station, USDA Forest Service, Washington, DC, USA, pp. 81-88. [online] URL: http://www.treesearch.fs.fed.us/ pubs/40735

Weber P, Bugmann $\mathrm{H}$, Pluess AR, Walthert L, Rigling A (2013). Drought response and changing mean sensitivity of European beech close to the dry distribution limit. Trees 27: 171-181. - doi: 10.1007/s00468-012-0786-4

Zimmerman NB, Vitousek PM (2012). Fungal endophyte communities reflect environmental structuring across a Hawaiian landscape. Proceedings of the National Academy of Science USA 109: 13022-13027. - doi: 10.1073/pnas.120987 2109 